Zeszyty Naukowe Szkoły Głównej Gospodarstwa Wiejskiego

Ekonomika i Organizacja Gospodarki Żywnościowej nr 114, 2016: 45-55

Agnieszka Rybowska

Katedra Handlu i Usług, Akademia Morska w Gdyni

\title{
Powszechne przekonania dotyczące wybranych zachowań żywieniowych w opinii konsumentów 65+
}

\section{Wstęp}

W badaniach rynkowych wiele uwagi poświęca się czynnikom determinującym zachowania konsumentów. Powstało wiele różnych podziałów uwzględniających determinanty związane z konsumentem, z produktem, czynniki społeczne i ekonomiczne ${ }^{1}$ lub, tak jak w rozbudowanych modelach, bardziej szczegółowe (zdrowotne, kulturowe, edukacyjne, zewnętrzne i wewnętrzne) ${ }^{2}$. Współcześnie coraz więcej uwagi przywiązuje się do czynników psychologicznych i społecznych. Ważną rolę w procesie podejmowania decyzji zakupowych odgrywają opinie innych osób: członków rodziny, znajomych, ale również środowisk opiniotwórczych (środowiska naukowe, media). Zdarza się, że pozyskane w taki sposób informacje są nieprawdziwe, nie poparte żadnymi wiarygodnymi danymi, pochodzą z nierzetelnych źródeł albo są już nieaktualne. Mimo to funkcjonują one w społeczeństwie jako utarte przekonania, które można uznać za powszechne, tradycyjne, typowe, ale także za szablonowe czy stereotypowe.

\footnotetext{
${ }^{1}$ R. Shepherd: Dietary salt intake. Nutrition and Food Sciences 96, 1985, 10-11.

E. Babicz- Zielińska: Jakość żywności w ocenie konsumenckiej. Gdańskie Towarzystwo Naukowe, Gdańsk 2006, 44.

${ }^{2} \mathrm{M}$. Yoshida: Studies in the psychometric classification of odor. Japanese Psychological Research, 6,111, 1964, 124-155.

M.A. Khan: Evaluation of food selection patterns and preferences. CRS Crittical Reviewof Food Science and Nutrition 15, 1981, 129-153.
} 


\section{Stereotypy w żywieniu}

Funkcjonujące w społeczeństwie utarte przekonania, nie zawsze zgodne $\mathrm{z}$ najnowszą wiedza, nazywa się stereotypem. Pojęcie to wywodzi się z nauk psychologicznych i socjologicznych, gdzie odnoszono je do człowieka. Lipmmann określił je jako jednostkowy, cząstkowy obraz powstający w głowie człowieka, przedstawiający obce grupy społeczne, powstający nie w wyniku własnego doświadczenia, ale na podstawie opornego na zmiany przekazu społecznego ${ }^{3}$. Kopaliński rozszerzył pojęcie stereotypu do rzeczy, osób, instytucji, wskazując tym samym, iż proces stereotypizacji dotyczy wielu aspektów życia człowieka ${ }^{4}$. Mylnie stereotypy kojarzy się z cechami negatywnymi. Istnieją też stereotypy pozytywne, które odnoszą się do cech aprobowanych przez społeczeństwo, np. matka Polka. Ten przykład wskazuje również na sens funkcjonowania stereotypów. Ich głównym celem jest „myślenie na skróty”, a więc stanowią one pewien schemat myślowy, który jest przekazem określonych informacji, ale nie wymaga szczególnego analizowania problemu, a samo stwierdzenie jest krótkie i powszechnie zrozumiałe. Posługiwanie się stereotypem ułatwia przekazywanie informacji, a tym samym upraszcza komunikację, ułatwia także podejmowanie decyzji, kreowanie osądów i wyobrażenie o ludziach lub produktach. Współcześnie najczęściej funkcjonują stereotypy płci, grup społecznych, narodowości, zawodów, młodych i starszych ludzi. Można je przypisać do produktów lub marki. Odnoszą się również do sposobu myślenia o żywności $i^{5}$ oraz do żywienia. Te ostatnie mogą wpływać na sposób żywienia i stanowić swoiste zagrożenie dla zdrowia człowieka. Do zagrożeń takich można zaliczyć błędne nawyki żywieniowe, a w ich wyniku złe odżywianie, niedobory witamin i mikroelementów lub ich nadwyżki, wynikające z przekonania o konieczności ciąłej suplementacji, powstawanie zaburzeń żywieniowych (otyłość, anoreksja), pojawianie się chorób dietozależnych ${ }^{6}$.

Stereotypy żywieniowe, które zakorzeniają się w świadomości społeczeństwa mają różne źródła: kulturowe - przeświadczenia przekazywane z pokolenia na pokolenie, będące wynikiem wiedzy ludowej, media - prasa szczególnie kobieca, telewizja, a obecnie także Internet, a w nim szczególną rolę spełniają social media, źródła naukowe - co pewien czas do konsumentów docierają nowe wyniki badań, które w danym momencie są odkrywcze, ale po pewnym czasie inne badania im zaprzeczają. Problem polega na tym, że nie wszystkie informa-

\footnotetext{
${ }^{3}$ Z. Chlewiński, I. Kurcz: Stereotypy i uprzedzenia, PAN, Warszawa 1992.

${ }^{4}$ W. Kopaliński: Słownik wyrazów obcych, Wyd. Swiat Książki, Warszawa 2000.

${ }^{5}$ M. Jeżewska-Zychowicz: Stereotypy w myśleniu o żywności w kontekście jej wptywu na mase ciała, Roczn. PZH 58, nr 2, 2007.

${ }^{6}$ A. Rybowska: Mity i stereotypy żywieniowe, Zeszyty Naukowe AM, Gdynia 2014.
} 
cje i ich aktualizacje docierają do przeciętnego konsumenta. Można odnieść do tego wiele przykładów. Mówiono o szpinaku, który zawiera bardzo dużo żelaza i zalecany jest szczególnie w żywieniu dzieci, o szkodliwości spożywania jajek jako źródła cholesterolu i o prozdrowotnym charakterze margaryny, która nie zawierała cholesterolu, a tym samym była zdrowsza od masła, itd. Konsument, posiadający małą wiedzę, ufa wszelkim tego typu przekazom. Młodsze pokolenia konsumentów, dysponując szerokim dostępem do wiedzy, ma możliwość weryfikowania zasłyszanych informacji w różnych źródłach, nadążania za nowymi doniesieniami. Nie można tego powiedzieć o osobach starszych, które na ogół pozbawione takich umiejętności, ufnie opierają swoją wiedzę na wskazanych wcześniej źródłach.

\section{Zachowania żywieniowe seniorów}

W ostatnich latach dużo uwagi poświęca się problemowi starzejących się społeczeństw. Wzrost liczby osób starszych zmusza do bliższego przyjrzenia się tej części społeczeństwa, monitorowania ich zachowań rynkowych i dostosowywania oferty do potrzeb tej grupy. Jednocześnie stanowi to podstawę do edukowania kolejnych pokoleń do pomyślnej starości ${ }^{7}$, a więc wcześniejszego uświadamiania znaczenia zdrowego stylu życia i aktywności społecznej dla okresu starości ${ }^{8}$.

Wraz z postępującym wiekiem zmieniają się zalecenia żywieniowe. Starsze osoby, ze względu na zmiany zachodzące w ich organizmach (spowolnienie metabolizmu, przewlekłe choroby), powinny modyfikować swoje nawyki i zachowania żywieniowe. Jak pokazują badania, ta grupa konsumentów popełnia wiele błędów żywieniowych, nie uwzględniając zaleceń, a kierując się własnymi przekonaniami i przyzwyczajeniami. Spożywane przez nich posiłki są nieregularne, jest ich zbyt mało i nie są urozmaicone. W diecie za mało jest posiłków ciepłych, gotowanych na parze lub duszonych ${ }^{9}$.

Dane statystyczne GUS z 2014 roku pokazują, że starsze osoby, w przeliczeniu na osobę na miesiąc, spożywają dużo jaj (16 szt.), mleka (3,95 1), ziemniaków $(5,25 \mathrm{~kg})$, warzyw $(11,91 \mathrm{~kg})$, owoców $(4,72 \mathrm{~kg})$ i mięsa $(6,75 \mathrm{~kg})$. Zdecydowanie mało ryżu $(0,22 \mathrm{~kg})$, kasz $(0,21 \mathrm{~kg})$, makaronów $(0,44 \mathrm{~kg})$ i ryb $(0,48 \mathrm{~kg})^{10}$.

\footnotetext{
${ }^{7}$ J. Halicki: Potoczne definicje pomyślnego starzenia się [w:] Pomyślne starzenie się w perspektywie nauk społecznych i humanistycznych, red. J.T. Kowaleski i P. Szukalski, Zakład Demografii i Gerontologii Społecznej UŁ, Łódź 2008.

${ }^{8}$ H. Zielińska-Więczkowska, K. Kędziora-Kornatowska, T. Kornatowski: Starość jako wyzwanie, Gerontologia Polska, t. 16, nr 3, 2008.

${ }^{9}$ B. Piórecka: Zasady żywienia osób starszych, http://dieta.mp.pl

${ }^{10}$ Mały rocznik statystyczny Polski, GUS, Warszawa 2015.
} 
Jednak w porównaniu do innych rodzin (pracowników i rolników) są to wartości duże. Jedynie spożycie mleka, ziemniaków i cukru jest większe w rodzinach rolników. W rodzinach emerytów i rencistów odnotowano małe spożycie soków owocowych i warzywnych, jogurtów oraz serów dojrzewających i topionych.

Starsi ludzie większość swego życia przeżyli w dobie gospodarki centralnej planowanej: w okresie biedy, nikłej dostępności towarów, a także małej dostępności do wiedzy. Bardzo często źródłem tej wiedzy były przekazywane z pokolenia na pokolenie mądrości ludowe, wiedza oparta na własnym doświadczeniu oraz informacje zaczerpnięte $\mathrm{z}$ mediów, ale często w różny sposób interpretowane. Właśnie takie utarte i zakorzenione w społeczeństwie przekonania wpływają na zachowania konsumentów. Stanowi to ryzyko powielania fałszywych stereotypów żywieniowych, gdyż wiedza i zachowania żywieniowe starszych osób mogą być przekazywane młodszym pokoleniom $\mathrm{w}$ ich rodzinach.

\section{Cel i metodyka pracy}

Przeprowadzono badanie, którego celem było poznanie opinii starszych osób na temat powszechnie utartych przekonań dotyczących żywności i żywienia.

W grupie konsumentów w wieku $65+$ określono preferencje dotyczące typowych potraw kuchni polskiej i wybranych produktów spożywczych oraz częstość ich spożycia. Badano opinie respondentów odnośnie stereotypowych stwierdzeń dotyczących żywności i żywienia.

W badaniu zastosowano metodę ankiety bezpośredniej. Kwestionariusz składał się z 5 pytań, w których zastosowano różne skale:

- pięciostopniową, werbalną skalę hedoniczną do oceny stopnia lubienia wybranych produktów spożywczych i dań (od bardzo nie lubię - 1 do bardzo lubię -5 , z miejscem neutralnym - jest mi to obojętne -3 );

- czterostopniową skalę pozycyjną do oceny częstości spożycia (często - 4, czasami - 3, rzadko - 2, nigdy - 1);

- skalę Likerta do oceny funkcjonujących w społeczeństwie przekonań dotyczących żywności i żywienia. Stwierdzenia dobrano na podstawie badań pilotażowych oraz studiów literaturowych.

Pytanie 5 dotyczyło źródeł informacji o żywności i żywieniu.

Wyniki badań przedstawiono jako wartość średnią.

Badanie przeprowadzono w 2015 roku w grupie 160 mieszkańców Gdyni. Badaną populację stanowiło 96 kobiet i 64 mężczyzn. Wszyscy byli uczestnikami Uniwersytetu Trzeciego Wieku. Dokonano celowego doboru próby: do badania zaproszono osoby w wieku powyżej 65 lat. 


\section{Analiza zachowań żywieniowych konsumentów 65+}

Starsi konsumenci preferują tradycyjne potrawy kuchni polskiej (tabela 1). W rankingu na najwyższych pozycjach znalazły się gołąbki, rosół, ziemniaki. Bardzo lubiane są dania z drobiu (kurczak pieczony, kotlet z piersi kurczaka), pierogi, zupa pomidorowa oraz karkówka pieczona. W grupie tej znalazły się też, uznawane za najpopularniejsze dania kuchni polskiej, bigos i kotlet schabowy, ale uplasowały się one dopiero na ósmym i dziesiątym miejscu. Kotlet z piersi kurczaka nie należy do dań tradycyjnych, ale w ostatnich latach zyskał dużą popularność i jest bardzo lubiany. Wpływa na to jego charakterystyczną delikatność i miękkość odpowiednią dla osób starszych.

Tabela 1

Stopień lubienia wybranych produktów spożywczych i potraw

\begin{tabular}{|r|l|c|c|c|}
\hline \multicolumn{1}{|c|}{ Lp. } & \multicolumn{1}{|c|}{ Produkt } & Xśr. & SD & Stopień lubienia \\
\hline 1 & \multicolumn{1}{|c|}{2} & 4 & \multicolumn{1}{|c|}{5} \\
\hline 1 & gołąki & 4,60 & 0,48 & \\
\hline 2 & rosół & 4,56 & 0,67 & \multirow{2}{*}{ bardzo lubiane } \\
\hline 3 & ziemniaki & 4,52 & 0,53 \\
\hline 4 & Kurczak pieczony & 4,44 & 0,57 \\
\hline 5 & zupa pomidorowa & 4,42 & 0,61 \\
\hline 6 & kotlet z piersi & 4,35 & 0,75 \\
\hline 7 & pierogi & 4,31 & 0,58 \\
\hline 8 & bigos & 4,29 & 0,64 \\
\hline 9 & karkówka pieczona & 4,23 & 0,71 \\
\hline 10 & kotlet schabowy & 4,23 & 0,54 & \\
\hline 11 & kapuśniak & 4,19 & 0,66 \\
\hline 12 & grochówka & 4,00 & 0,79 \\
\hline 13 & zrazy & 3,96 & 0,82 \\
\hline 14 & twarogi & 3,96 & 0,86 \\
\hline 15 & kotlet mielony & 3,96 & 0,82 \\
\hline 16 & kaczka pieczona & 3,92 & 1,11 \\
\hline 17 & ryba smażona & 3,92 & 0,86 \\
\hline 18 & miód & 3,83 & 0,58 \\
\hline 19 & de volaille & 3,75 & 0,91 \\
\hline 20 & kawa & 3,75 & 0,92 \\
\hline 21 & flaki & 3,73 & 0,95 \\
\hline 22 & sery & 3,73 & 0,64 \\
\hline 23 & mleko & 3,54 & 0,76 & \multirow{2}{*}{ lubiane } \\
\hline & & & \\
\hline
\end{tabular}


cd. tabeli 1

\begin{tabular}{|l|l|c|c|c|}
\hline 1 & \multicolumn{1}{|c|}{2} & 3 & 4 & \multirow{2}{*}{5} \\
\hline 24 & pulpety & 3,35 & 0,86 & \multirow{2}{*}{} \\
\hline 25 & soki & 3,25 & 1,13 & \\
\hline 26 & płatki & 3,21 & 0,72 & \multirow{2}{*}{ obojętne } \\
\hline 27 & zupa mleczna & 3,10 & 1,15 & \\
\hline 28 & wino & 3,10 & 0,84 & \\
\hline 29 & spaghetti & 3,08 & 1,31 & \\
\hline 30 & kasze & 3,04 & 0,73 & \\
\hline 31 & pizza & 2,88 & 1,05 & \\
\hline 32 & piwo & 2,88 & 1,16 & \\
\hline 33 & wódka & 2,58 & 0,78 & \multirow{2}{*}{ nielubiane } \\
\hline 34 & napoje gazowane & 2,50 & 1,18 & \\
\hline 35 & szpinak & 2,40 & 0,86 & \multirow{2}{*}{ bardzo nielubiane } \\
\hline 36 & zupa owocowa & 1,96 & 1,04 & \\
\hline 37 & boeuf Stroganow & 1,81 & 1,74 & \\
\hline 38 & dania chińskie & 1,38 & 1,75 & \multirow{2}{*}{} \\
\hline
\end{tabular}

Źródło: Badania własne.

Grupa produktów i potraw lubianych jest bardzo zróżnicowana. Zakwalifikowały się do niej produkty mleczarskie, dania mięsne (zrazy, flaki, kaczka pieczona, kotlet mielony, ryba smażona), popularne zupy (kapuśniak, grochówka). De volaille jest również lubiany, chociaż, podobnie jak kotlet z piersi, nie zalicza się do dań tradycyjnych. $\mathrm{W}$ grupie produktów nielubianych znalazły się zupa owocowa, szpinak napoje gazowane, wódka, a bardzo nielubiane były dania chińskie i boeuf Stroganow. Inne alkohole (wino, piwo) zakwalifikowano jako obojętne dla tej grupy badanych. Ani lubiane, ani nie lubiane były również dania z mlekiem (zupa mleczna, płatki), dania kuchni włoskiej (pizza, spaghetti), soki oraz kasze, które respondentom mogą kojarzyć się z okresem niedoborów żywności i mimo swoich walorów prozdrowotnych nie są lubiane.

W kolejnym pytaniu badanych zapytano o częstość spożycia wybranych produktów spożywczych, które odpowiadały produktom wskazanym w ocenie stopnia lubienia (tabela 2).

Do najczęściej spożywanych zaliczono ziemniaki: warzywa, wędliny, mleko, wieprzowinę. Seniorzy często konsumują drób, margarynę, ser żółty, makarony i ryż. Miód jest również często spożywany. Rzadko spożywa się nielubiany szpinak, kasze, soki, wołowinę, ryby oraz alkohole. Owoce morza nie są spożywane. 
Tabela 2

Częstość spożycia wybranych produktów żywnościowych

\begin{tabular}{|c|c|c|c|c|}
\hline Lp. & Produkt & Xśr. & SD & Częstość spożycia \\
\hline 1 & ziemniaki & 3,88 & 0,38 & \multirow{9}{*}{ często } \\
\hline 2 & warzywa & 3,60 & 0,48 & \\
\hline 3 & wędliny & 3,52 & 0,54 & \\
\hline 4 & mleko & 3,48 & 0,54 & \\
\hline 5 & wieprzowina & 3,48 & 0,49 & \\
\hline 6 & jajka & 3,38 & 0,56 & \\
\hline 7 & owoce krajowe & 3,33 & 0,68 & \\
\hline 8 & herbata & 3,31 & 0,82 & \\
\hline 9 & twaróg & 3,29 & 0,68 & \\
\hline 10 & oliwa, olej & 3,19 & 0,64 & \multirow{9}{*}{ czasami } \\
\hline 11 & ser żółty & 3,17 & 0,72 & \\
\hline 12 & drób & 3,15 & 0,71 & \\
\hline 13 & kapusta, kapustne & 3,04 & 0,73 & \\
\hline 14 & herbaty ziołowe & 2,96 & 0,91 & \\
\hline 15 & miód & 2,71 & 0,81 & \\
\hline 16 & margaryna & 2,67 & 0,66 & \\
\hline 17 & makarony & 2,44 & 0,64 & \\
\hline 18 & ryż & 2,44 & 0,64 & \\
\hline 19 & kasze & 2,40 & 0,81 & \multirow{10}{*}{ rzadko } \\
\hline 20 & ryby & 2,31 & 0,51 & \\
\hline 21 & owoce egzotyczne & 2,29 & 0,54 & \\
\hline 22 & soki & 2,29 & 0,79 & \\
\hline 23 & szpinak & 2,25 & 0,87 & \\
\hline 24 & wino & 2,23 & 0,62 & \\
\hline 25 & wołowina & 2,19 & 0,49 & \\
\hline 26 & masło & 2,04 & 0,86 & \\
\hline 27 & piwo & 1,77 & 0,82 & \\
\hline 28 & wódka & 1,71 & 0,71 & \\
\hline 29 & owoce morza & 1,21 & 0,49 & nigdy \\
\hline
\end{tabular}

Źródło: Badania własne. 


\section{Funkcjonujące w społeczeństwie stereotypy w opinii osób starszych}

Starsze osoby posiadają wiedzę opartą na doświadczeniu własnym i wcześniejszych pokoleń. Oprócz tego czerpią ją z prasy kobiecej (35\%), telewizji $(30 \%)$, od znajomych (22\%), rodziny (15\%). Rzadko sięgają po źródła naukowe (2\%). Starsi ludzie rzadko śledzą doniesienia naukowe dotyczące żywienia (13\%). Jednak zapadają one w pamięci, tworząc z czasem głęboko zakorzenione przekonania. Do takich zalicza się na przykład stwierdzenia, że szpinak zawiera dużo żelaza, gorąca herbata $\mathrm{z}$ cytryną albo gorące mleko z miodem dobrze działają na przeziębienia, cytryna jest najlepszym źródłem witaminy C. Panuje również przekonanie, iż ziemniaki są tuczące, a owoce można zjadać bez ograniczeń. Takich przykładów jest wiele, ale jak widać na wcześniej wymienionych przykładach, mimo iż w każdym $\mathrm{z}$ nich jest odrobina prawdy, ale nie jest to równoważne ze stwierdzeniem. Każde z nich obarczone jest błędem. W tabeli 3.

Tabela 3

Funkcjonujące w społeczeństwie opinie dotyczące produktów żywnościowych

\begin{tabular}{|c|c|c|c|c|}
\hline Lp. & Stwierdzenie & $\mathrm{X}_{\text {śr. }}$ & SD & $\begin{array}{l}\text { Odpo- } \\
\text { wiedź }\end{array}$ \\
\hline 1 & Cytryna jest najlepszym źródłem witaminy C & 4,77 & 0,51 & \multirow{5}{*}{ 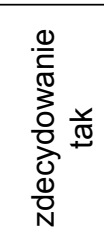 } \\
\hline 2 & Herbata z cytryną dobrze działa na przeziębienie & 4,73 & 0,48 & \\
\hline 3 & Miód z gorącym mlekiem dobrze działa na przeziębienia & 4,69 & 0,68 & \\
\hline 4 & Szpinak jest dobrym źródłem żelaza & 4,27 & 0,61 & \\
\hline 5 & Picie dużych ilości mleka chroni przed osteoporozą & 4,13 & 0,83 & \\
\hline 6 & Ziemniaki są tuczące & 4,10 & 1,01 & \multirow{10}{*}{ 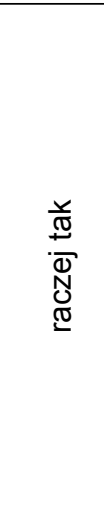 } \\
\hline 7 & Soki są bardzo zdrowe i należy je pić & 4,10 & 0,77 & \\
\hline 8 & Konserwanty są bardzo szkodliwe dla zdrowia & 4,08 & 0,73 & \\
\hline 9 & $\begin{array}{l}\text { Ze względu na właściwości odżywcze owoce można zjadać } \\
\text { bez ograniczeń }\end{array}$ & 3,83 & 1,12 & \\
\hline 10 & Twarogi są dobrym źródłem wapnia & 3,71 & 0,61 & \\
\hline 11 & Tłuszcze powodują tycie, a nie są potrzebne dla organizmu & 3,54 & 0,99 & \\
\hline 12 & Oliwa nie tuczy & 3,50 & 1,04 & \\
\hline 13 & Warto spożywać suplementy diety & 3,35 & 0,81 & \\
\hline 14 & Dania typu „fast food” są szkodliwe & 3,33 & 1,11 & \\
\hline 15 & Codziennie należy wypić lampkę wina & 3,27 & 1,05 & \\
\hline 16 & Margaryna jest lepsza niż masło & 2,92 & 1,13 & \multirow{3}{*}{ 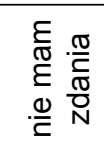 } \\
\hline 17 & Kawa wspomaga odchudzanie & 2,85 & 0,52 & \\
\hline 18 & Mięso drobiowe jest najzdrowsze & 2,69 & 1,21 & \\
\hline
\end{tabular}

Źródło: Badania własne. 
pokazano odpowiedzi badanych, którzy w większości zgadzają się z podanymi stwierdzeniami. Respondenci nie udzieli odpowiedzi „raczej nie” i ,zdecydowanie nie".

Podobne wyniki uzyskano we wcześniejszym badaniu przeprowadzonym wśród osób młodych i w średnim wieku. Wykazano, iż badani zgadzają się z wieloma stwierdzeniami. Jednocześnie potwierdzili oni, iż w ich opinii stereotypy wpływają na zachowania żywieniowe ${ }^{11}$. Istnieją również sformułowania dotyczące zachowań żywieniowych, które opierają się na utartych w społeczeństwie przekonaniach (tabela 4). W świadomości osób 65+ funkcjonuje przekonanie, iż najlepsze jest to, co przygotowuje się samodzielnie. Respondenci zgadzaja się również z tym, że mężczyźni lubią konkretne dania i dużo, preferują mięso wieprzowe, podczas gdy kobiety wolą drobiowe. Stwierdzają, iż ulubione danie Polaków to schabowy i bigos, a swoim zachowaniem (wysokim stopniem lubienia tych dań) potwierdzają to przekonanie. Badani zgadzają się, że na obiad muszą być ziemniaki, które stanowią tradycyjny dodatek do obiadu, a w rankingu preferencji znajdują się $\mathrm{w}$ grupie najbardziej lubianych. W podanym zestawie stwierdzeń są też takie, w stosunku do których respondenci mieli wątpliwości:

\section{Tabela 4}

Funkcjonujące w społeczeństwie opinie dotyczące zachowań żywieniowych i poglądów związanych z żywieniem

\begin{tabular}{|c|c|c|c|c|}
\hline Lp. & Stwierdzenie & $\mathrm{X}_{\text {śr. }}$ & SD & $\begin{array}{l}\text { Odpo- } \\
\text { wiedź }\end{array}$ \\
\hline 1 & Najlepsze jest to, co sam przygotujesz & 4,69 & 0,59 & \multirow{7}{*}{  } \\
\hline 2 & Mężczyźni lubią konkretne dania i dużo & 4,67 & 0,59 & \\
\hline 3 & Ulubione danie Polaków to schabowy i bigos & 4,58 & 0,72 & \\
\hline 4 & Omijanie posiłków pomaga schudnąć & 3,58 & 0,81 & \\
\hline 5 & Mężczyźni wolą mięso wieprzowe, a kobiety drobiowe & 4,27 & 0,88 & \\
\hline 6 & Palenie papierosów negatywnie wpływa na zdrowie & 4,27 & 1,13 & \\
\hline 7 & Na obiad muszą być ziemniaki & 4,21 & 0,56 & \\
\hline 8 & Polacy piją dużo alkoholu & 3,94 & 0,92 & \multirow{4}{*}{ 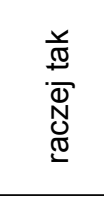 } \\
\hline 9 & Otyłe osoby to obżartuchy & 3,81 & 1,09 & \\
\hline 10 & Kobiety wybierają delikatne dania & 3,69 & 1,12 & \\
\hline 11 & Kobieta w ciąży musi jeść za dwóch & 3,65 & 0,96 & \\
\hline 12 & Osoby bardzo szczupłe mają anoreksję & 3,27 & 0,80 & \multirow{3}{*}{ 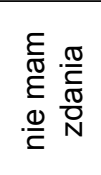 } \\
\hline 13 & Jesteś tym, co jesz & 3,13 & 0,66 & \\
\hline 14 & $\begin{array}{l}\text { Picie od czasu do czasu lampki wina w trakcie ciąży nie } \\
\text { zaszkodzi, a może poprawić wyniki }\end{array}$ & 2,19 & 1,13 & \\
\hline
\end{tabular}

Źródło: Badania własne.

\footnotetext{
${ }^{11}$ A. Rybowska: Stereotypy zywieniowe i ich wplyw na zachowania konsumentów, Probl. Higieny i Epidemiologii 94 (3), 2013.
} 
raczej zgadzają się z nimi lub nie mają zdania. Można przypuszczać, iż te właśnie stwierdzenia budzą ich wątpliwości, nie mają wiedzy w danym zakresie albo są to zagadnienia nowe, bądź niezrozumiałe (np. jesteś tym, co jesz).

Podobnie jak wcześniej, i tutaj badani nie udzieli odpowiedzi „raczej nie” i ,zdecydowanie nie”.

\section{Podsumowanie}

Analizując powyższe dane, można zauważyć zależności między funkcjonującymi w społeczeństwie przekonaniami a zachowaniami żywieniowymi ankietowanych:

Szpinak w opinii badanych jest dobrym źródłem żelaza, jednocześnie nie jest produktem lubianym przez konsumentów, a mimo to spożywanym.

Bigos i schabowy uznawane są za ulubione dania Polaków, co potwierdza również wysoki stopień lubienia tych potraw w badanej grupie.

Ziemniaki są nieodłącznym elementem obiadu. Badani zgadzają się z tą opinią, a ziemniaki są przez nich bardzo lubiane i często spożywane.

Badania pokazują, iż starsi konsumenci są zgodni, co do wielu funkcjonujących w społeczeństwie przekonań, które nie zawsze zgodne są z aktualną wiedzą żywieniową. Wskazuje to na konieczność docierania do środowisk osób starszych i promowania wśród nich prawidłowych nawyków żywieniowych.

\section{Literatura}

BABICZ-ZIELIŃSKA E.: Jakość żywności w ocenie konsumenckiej. Gdańskie Towarzystwo Naukowe, Gdańsk 2006.

CHLEWIŃSKI Z., KURCZ I.: Stereotypy i uprzedzenia, PAN, Warszawa 1992.

HALICKI J.: Potoczne definicje pomyślnego starzenia się, [w:] Pomyślne starzenie sie w perspektywie nauk społecznych i humanistycznych, red. J.T. Kowaleski i P. Szukalski, Zakład Demografii i Gerontologii Społecznej UŁ, Łódź 2008.

JEŻEWSKA-ZYCHOWICZ M.: Stereotypy w myśleniu o żywności w kontekście jej wplywu na mase ciała, Roczn. PZH, 58, nr 2, 2007.

KHAN M.A.: Evaluation of food selection patterns and preferences. CRS Crittical Review of Food Science and Nutrition 15, 1981.

KOPALIŃSKI W.: Słownik wyrazów obcych, Wyd. Świat Książki, Warszawa 2000.

Mały rocznik statystyczny Polski, GUS, Warszawa 2015.

PIÓRECKA B.: Zasady żywienia osób starszych, http://dieta.mp.pl

RYBOWSKA A.: Mity $i$ stereotypy żywieniowe, Zeszyty Naukowe AM, Gdynia 2014.

RYBOWSKA A.: Stereotypy żywieniowe i ich wplyw na zachowania konsumentów, Probl.

Higieny i Epidemiologii 94 (3) 2013.

SHEPHERD R.: Dietary salt intake. Nutrition and Food Sciences 96, 1985. 
YOSHIDA M.: Studies in the psychometric classification of odor. Japanese Psychological Research 6, 111, 1964.

ZIELIŃSKA-WIĘCZKOWSKA H., KĘDZIORA-KORNATOWSKA K., KORNATOWSKI T.: Starość jako wyzwanie, Gerontologia Polska, t. 16, nr 3, 2008.

\title{
Abstrakt
}

Konsumenci podejmując decyzje zakupowe, często kierują się nie aktualną wiedzą, ale zakorzenionymi w ich świadomości przekonaniami, które tej wiedzy przeczą. Celem przeprowadzonych badań było określenie wpływu funkcjonujących w społeczeństwie utartych przekonań na zachowania żywieniowe starszych osób. Badania przeprowadzono w grupie 160 seniorów pochodzących z Trójmiasta. Wykazano, iż seniorzy zgadzają się z wieloma stereotypami, a ich zachowania żywieniowe często odpowiadają tymże przekonaniom.

Słowa kluczowe: starsi konsumenci, stereotypy, zachowania żywieniowe, żywienie

\section{Common belief on selected food consumption behaviors in the opinion of consumers $65+$}

\begin{abstract}
Consumers making purchasing decisions are often guided not by the latest knowledge, but rooted in their consciousness beliefs that deny this knowledge. The aim of this study was to determine the effect of common beliefs functioning in society, affecting food consumption behavior of elderly people. The study was conducted in a group of 160 seniors from conurbation of Gdańsk, Gdynia and Sopot. It has been shown that seniors agree with many stereotypes, and their eating behavior often corresponds with their convictions.
\end{abstract}

Key words: older consumers, stereotypes, food consumption behavior, nutrition 